\title{
Managing Protected Areas: A Global Guide
}

Review of: Michael Lockwood, Graeme Worboys and Ashish Kothari, (eds). Earthscan, London, 2006, xxx+802 pp, ISBN978-1-84407-303-0 figs, tables, index.

Ralf C Buckley

Griffith University, Australia

A mammoth tome indeed, this giant compendium originated as an internationalised version of the Australian text on Protected Area Management by Graeme Worboys et al.; but contains so much more material that it can only be considered as an entirely separate text. Some statistics show its size: 26 chapters, six appendices, 18 colour plates, 57 figures, 70 tables, 25 text boxes, 178 case studies, 69 contributors and 21 reviewers, and a list of around 200 acronyms. As the editors say in their introduction (p.xxvi), this is indeed "a compendium of material that has not been hitherto available at a global scale in a single volume".

As representatives of the commercial tourism industry so frequently like to remind us, many protected areas worldwide were established for recreation as well as conservation; and as parks agencies like to remind us, managing park visitors commonly consumes far more of their staff time and budgets than managing natural resources. What, then, does this book have to tell us about tourism in parks? From a tourism researcher's perspective, there are perhaps three threads of information. The first is simply to take the book at face value, a representation of how senior staff and researchers in protected area management see their own role. From this we would conclude, perhaps, that tourism and recreation are rather minor considerations in protected area management. The second thread is to pick out the particular pieces of text which refer indirectly to tourism and recreation, albeit under other headings. Table 9.1, for example, (pp.225-227) lists a set of 30 threats to protected areas, of which two are related to tourism: "on-site infrastructure and tourism development" and 
"unsustainable visitor use". Chapter 12, on finance and economics, contains several case studies on fees for tourism and recreation (pp.344-350).

The third thread is provided by the book's single chapter specifically on tourism and recreation, covering some 30 pages (pp.497-527). Of these, 10 pages are taken up by individually-authored case studies, two by illustrations, and four by tables drawn from other sources, principally the New South Wales National Parks and Wildlife Service and the 2002 book on Natural Areas Tourism by David Newsome and his colleagues. The remaining text consists largely of connective tissue which ties together these extracts and case studies. This is organised under eight major headings, entitled respectively: global tourism and environmental performance; the tourism industry; visitor management models; visitor service and support; visitor monitoring; interpretation of protected area values; local community involvement in tourism; and management principles. The approach is one of compilation rather than analysis. It does also refer the reader to the 2003 report on Tourism and Biodiversity by Conservation International, and to the well-known 2002 book on Tourism in National Parks by Paul Eagles and Stephen McCool. There are, however, many well-respected and relevant volumes which do not receive even a mention. What about the many published works by US researchers such as Cole, Dawson, Fennell, Field, Hendee, Lime, Manning, Marion, Stankey, Weaver and many more, or Australians such as Jenkins and Pigram?

A text such as this, aimed at students and practitioners of protected area management worldwide, necessarily emphasises the well-known and conventional aspects of the topic rather than the particular issues which may be of current interest to researchers. Accordingly, whilst private and community protected areas, and various multi-stakeholder partnerships, do receive a mention at intervals, the principal focus is on public parks and protected areas. 
There is a chapter on community conserved areas and another on collaboratively managed protected areas, both written by Ashish Kothari, and one on landscape-scale linkages. There is rather little, however, on private protected areas: a paragraph on pp.119-120, and a short case study on p.129. The emphasis is strongly terrestrial, though there is one chapter specifically on marine protected areas.

Taking the book on its own terms, as a training manual for protected area management in Anglophone countries worldwide, we must certainly congratulate the editors and contributors for drawing together such a wealth of valuable material in a structured and comprehensible format. From the particular perspective of tourism research, the main conclusion would seem to be that protected area managers don't actually see tourism and recreation as a very significant part of their task. And at a global scale, perhaps that is indeed how things should be. And closer to home, for those of us who happen to work on tourism in and around protected areas, perhaps it is a useful reminder that our favourite topic is only a very small part of a very big picture.

Ralf Buckley International Centre for Ecotourism Research

Griffith University Gold Coast, Queensland, Australia, 4215 Tel: +61 (0)7 55528675 Fax: +61 (0)7 55528895 E-mail: r.buckley@griffith.edu.au 